Keirl, S., (2015), 'Global ethics, sustainability, and Design and Technology

Education', in Stables, K. \& Keirl, S., (Eds.), (2015), Environment, Ethics

and Cultures: Design and Technology Education's Contribution to

Sustainable Global Futures, pp. 33-52, Sense, Rotterdam.

...FINAL DRAFT

STEVE KEIRL

\title{
GLOBAL ETHICS, SUSTAINABILITY, AND DESIGN AND TECHNOLOGY EDUCATION
}

\section{INTRODUCTION}

Evocative of both family and humankind-to-come, 'generations' is a common reference for sustainability. We look back and we look forward across generations and an implicit blend of emotion speaks to concerns for 'future generations' or 'inter-generational justice'. Five witnesses who share these concerns step forward from the past half-century, a period spanning almost three generations. Their motivations are the same motivations as this book's authors: the achievement of desirable global futures. The witnesses (and there is no shortage of others) all recognise that to achieve such futures what is needed is deep public engagement and an appropriately educated global citizenry. Each presents a radical yet articulate case; values participatory democracy while critiquing Western capitalist democracies; draws on history yet is futures-activist; is motivated by deep valuesbased concerns; and, recognises the enormity of the challenges they describe. They have said that:

(T)he environment for a satisfying style of life is being undermined by all the emphasis on ever-greater productivity and consumption. As a result, the nation faces the hazard of developing a healthy economy within the confines of a psychologically sick and psychologically impoverished society. (Packard, 1960/1963, p. 293)

The Greatest Resource - Education (Schumacher, 1974, p. 64). The problems of education are merely reflections of the deepest problems of our age...We are suffering from a metaphysical disease, and the cure must therefore be metaphysical. Education which fails to clarify our central convictions is mere training or indulgence. (Schumacher, 1974, p. 83)

A.N. Other, B.N. Other (eds.), Title of Book, 00-00.

(C) 2005 Sense Publishers. All rights reserved. 


\section{STEVE KEIRL}

Human beings are the only species with a history. Whether they also have a future is not so obvious. The answer will lie in the prospects for popular human movements, with firm roots among all sectors of the population, dedicated to values that are suppressed or driven to the margins within the existing social and political order: community, solidarity, concern for a fragile environment that will have to sustain future generations, creative work under voluntary control, independent thought, and true democratic participation in varied aspects of life. (Chomsky, 1989/2003, p. 136)

(Environmental Education) is a very broad area of educational activity from primary school to postgraduate. It is an amazingly mixed bag, spanning the worst of fuzzy thinking about "nature" to the best and most insightful methods of engaging how humanity currently dwells in the world and needs to do so in other ways. It is extremely important for it to transcend its original naturalistic terms of reference to embrace the "naturalised artificial". (Fry, 2009, p. 243)

If there is to be a search by the international community for a common ground, there must be a space for an intercultural dialogue on ethics. The international community must make an active effort to begin this process of dialogue and understanding, and to provide a space within which intercivilizational exchange can occur. (UNESCO, 2001, p. 1)

Thus, twenty-five years ago, Chomsky signalled the development, in so-called democracies, of the use of media for subtle ideological manipulation and control by governments themselves. (Similar critiques have been applied to education: see e.g. Apple, [2001]). Over fifty years ago Packard eloquently foregrounded issues not just about 'ardent materialism' and 'planned obsolescence' but also about the strategies of persuasion used by business to promote consumerism and consumption (Packard, 1957/1962; 1960/1963). In 2009 Fry, in advancing his notion of sustainment (the overcoming of the unsustainable) rails against greenwashing and argues for a re-imagined and revitalised approach to our design thinking and practices. Schumacher's 1974 classic advocated 'economics as if people mattered', 'technology with a human face' and 'intermediate technology'. At the turn of the Century, UNESCO anticipated the multiple ethical challenges facing humanity (and others) on the planet.

So why does it seem that despite over half a century of raised awareness, that the evidence, opinion and the literature continue to expand but real sustainable change seems as elusive as ever? If our knowledge about the issues is growing why are the problems not being resolved? Perhaps greenwash and scaremongering are working in favour of the vested interests that refuse to change. Perhaps we are led to think that positive change is happening or is just around the corner when, in reality, the only change is superficial or peripheral. Perhaps public global awareness is actually growing but has yet to reach the necessary critical mass for 
change. Assuming (which optimism suggests) that positive change is taking hold how will such change itself be sustainable?

This chapter argues that necessary, deep and lasting change needs to be considered as a matter of a global ethics that addresses multiple issues - amongst them, sustainability. It is not enough to claim to 'know' that sustainability is something we should all care about and act upon. The need is to see sustainability for its rich and problematic nature. Sustainability issues are matters of values contestation which, if they are to be properly understood, debated and resolved, need to engage with other fields of human collaboration and enterprise as well as across cultures. Especially, sustainability shares much with democracy and education. Because all three are to be cherished and have common ethical concerns, ethics offers a meta-discourse across the triad. Further, all three need to be able to 'speak' to each other as well as to any futures that might be shaped by them. To deepen this approach, each must be of, and for, the other. That is: education for democracy and sustainability; democracy for education and sustainability; and, sustainability for democracy and education.

Whatever 'democracy' means to different users of the term, for the purposes of this chapter I take it to be: government by the most ethically defensible means. I am not claiming here that this is a right answer or that I am right. I frame it this way to signal the need that it be continuously tested and con-tested both as a concept and as a means of co-existing. Democracy must remain under continuous ethical scrutiny and debate in order to remain democratic. When it ceases to be ethical, it ceases to be democratic - and when a system of government or coexistence ceases to be democratic, it is not ethical. Further, if this sense of democracy is viable, then the principles involved could, and should, extend globally.

In turn, if democracy is ethically determined then so must the education systems on which it is based and for which it exists. As White (1973) cogently argues, "There is at least one policy which must be in the public interest in a democracy. This is an appropriate education for a democracy." (White, 1973, p. 237. Original emphases). Thus education is key to the wellbeing of democracy and for the wellbeing of its participants. White also argues that the determination of what might constitute that 'appropriate education' cannot be left to 'experts' but that moral judgements are central to the determination of education in, and for, democracy. In short, we should all have a say in these matters.

Although not foregrounded in this chapter, Design and Technology Education is ever in the background. In parallel to the focus a global ethics and sustainability, all of technologies, designs and the acts of designing, creating and using technologies are themselves understood to be matters of ethical contestation. Design and Technology Education itself warrants an ethical-democratic curriculum role (Keirl, 2006a).

Finally, this chapter has considerable limitations and these are signalled at the end. In particular, there is a Western proclivity that cannot be denied. In part, this is because of the need for deeper study and research by the author. It is also because the general question under scrutiny is of Western making. It is largely the 
STEVE KEIRL

case that the origins of both problems and discourses around sustainability are Western. Arguably, then, Western discourses may or may not be appropriate tools for answering the question or meeting the problems. Thus, in arguing a case for looking at sustainability issues through ethical lenses it matters that some of the West's key understandings and constructs be critiqued.

Who do we think we are? (i)

The idea of 'self' begs some consideration as it turns up often enough across ethics-democracy-education-sustainability literature. 'Self' can denote any of: person, identity, individual, agent, actor (after Latour, 2007), being, choice-maker, moral entity, human, and more. In the Western world we can talk of the psychological self, the sociological self, the philosophical self. There are negations too - self as not 'the other', not an object, or not common.

Otherwise, as UNESCO (2001) alerts us, "For the Buddhist tradition...the beginning of ethics consists of a detachment of the 'self', of a 'no self' ...(and that) a 'self' in the Western sense may not be taken as a reference point for ethical theory. But one can translate the 'self' and 'self-relationship' to the term 'autonomy" (UNESCO, 2001 pp. 12-13). Meanwhile, in the Confucian tradition there is no equivalent to the modern Western notion of self and the individual. Rather, the Confucian self is "... a relational self, defined through social institutions and relationships, characterized by interrelatedness among family, friends, communities, countries and the universe, and is marked by a sense of mutuality, responsibility and obligation." (UNESCO, 2001, p. 15).

Within the Western frame a particular ethical concern is the notion of selfinterest. At one extreme there is the absolute selfishness that can be manifested in ruthlessness, winning, surviving, maximisation of personal assets, and so on. This selfishness holds the interests of particular persons above those of other persons, other species and the world at large. A contrasting position, long-established and gaining renewed currency is the recognition that our best 'self'-interests are actually served by looking after the 'common good' through cooperation and collaboration. In its deepest form, such a position affords equal rights to all species and environments.

Singer (1995) discusses the "age of self interest" suggesting that "...human nature may have evolved to be capable of more than narrow self-interest" (Singer, 1995, p. 24). He offers his broader conception of "enlightened self-interest" arguing that we are better served by working rationally and collaboratively than by working selfishly. In a subsequent work (Singer, 2004) advancing the case for a global ethical community, he discusses national self-interest and how ethical discourse is now looking beyond the idea of inter-national with its implicit assemblage of so many sovereign states with their own identities and borders, towards the goal of a one-world global community.

Wood (2007) talks of eco-solipsism - of the narcissistic self trying to 'be' in what he describes as 'the cult of celebrity, vanity, and self-presentation' and the development of "...a new ethics of the individual in which the environmental 
responsibilities of citizens became eclipsed by their implicit rights as consumers. Clearly, from an ecological perspective we can see that few individuals could adopt this mode of living without causing enormous environmental damage." (Wood, 2007, p. 35). More recently, Bennett (2010) takes self-interest in a different direction arguing that it could embrace her notion of the vibrant materiality that runs through all things, animate and inanimate (in the Latourian sense of attributing them with agency). As with Singer, Wood and many others, she will not dissolve the very relationships we inevitably hold with all matter and species. Thus, by acknowledging such interdependence we can adopt another kind of enlightened self-interest. Bennett argues that environmentalism, '...invented in the 1970s...', was, in the 2000s, making a comeback with a whole range of concerns and practical problems stirring an American public from their 'fatalistic passivity' (after Guattari). "This comeback was motivated in large part by self-interest, by a fear of the environmental 'blowback' of human actions." (Bennett, 2010, p. 110).

A key challenge to sustainability is that of anthropocentrism - a different sense of self-interest. To contemplate, analyse, speculate or critique from a solely human-centred position is to take either an academically selfish or an impoverished approach - or both. As with enlightened self-interest, we are collectively the poorer when we deliberately fail to see or acknowledge the 'other' which, alongside us, constitutes the global whole. To critique our anthropocentrism raises questions of our existence when we recognise that we, as persons, are not sole existences or beings but that our existence is actually a matter of multiple coexistences. Thus, we can consider ourselves as being-with or co-existing in four different realms: with other humans; with other species; with the planet; and, with technologies. This framing is not intended to be reductionist or anti-ecological in nature. It was offered (Keirl, 2010) to help educators engage with Technology's complexity and seeming invisibility in our everyday lives. Here, it is offered as the background against which sustainability can be contextualised.

A further concept to introduce in relation to 'self' is Bildung which has a rich history in German culture and is valid for the concerns of this chapter. Bildung offers a special sense of education - one that qualitatively exceeds the kinds of instrumentalist schooling being advanced in many contemporary societies. In his 1975 magnum opus critiquing Enlightenment reason, Gadamer (1975/2004) writes that Bildung is not a matter of ".... technical construction, but grows out of an inner process of formation and cultivation, and therefore constantly remains in a state of continual Bildung." (Gadamer, 1975/2004, p. 10). Bildung as such cannot be a goal - it is a continuous becoming with no goals outside of itself. It is not about the cultivation of particular talents (witness current instrumental educational agendas to 'train' and 'prepare' students for jobs and markets). It is at once both sustainable and sustaining.

Bildung as (self-)formation is holistic and lifelong with strong dimensions of self-reflection, self-critique and transformation. Rather than adopting a passive acceptance of some kind of 'natural consciousness', the aim is the development of “...working consciousness (which) contains all the elements that make up practical Bildung: the distancing from the immediacy of desire, of personal need and private 
STEVE KEIRL

interest, and the exacting demand of a universal." (Gadamer 1975/2004, p. 12). He also advances the need for receptivity to “...'otherness'... keeping oneself open to what is other - to other, more universal points of view...To distance oneself from oneself and from one's private purposes means to look at these in the way that others see them." (Gadamer 1975/2004, p. 15). In turn, what is sought is a "cultivated consciousness" which has "...more the character of a sense...It is a universal sense." (Gadamer 1975/2004, p. 16).

Bildung not only works holistically to develop a critical-ethical self but it also works to develop society and is ever self-questioning to 'build better'. The concept strongly epitomises the sustainable-self, the self who, through reflection and action, seeks to build for the greater good. In this light, growth is not of the kind the capitalist project promulgates. Rather, it is all of inward-, outward-, and futurefocused growth. It models a very enlightened self-interest that contributes to the common good.

\section{Who do we think we are? (ii)}

Something must be said about the term 'human' and such derivatives as humanity, humankind, human being, humanism and human nature. We use human and humankind to refer to our own species and we describe ourselves as human beings which usefully keeps a hint of the existential present - our be-ing human. But we also talk ethically of human behaviour, our shared humanity, inhumanity, humane treatment and so on. Some brief commentary on human nature and some exploration of post/humanism is needed.

In discussing sustainability, the concept of human nature (or any use of 'nature') is a shaky one. For one thing, it can be culturally specific in how it is applied. Indeed, for some cultures, the concept could be puzzling. To talk of a human nature as opposed to other natures or in the light of a unifying singular Nature begs contention. The need is that we are mindful of multiple, contextualised uses of 'human nature'. Warnock (1998, p. 21) reminds us that "natural" is a "slippery and evanescent" concept. Nature, for some, is just stuff, a thing, or so many materials. In educating for sustainability, we know now that we should think otherly, as Wood (2007, p. 188) does when he invites us to see Nature as "emergence and flow".

Philosophically, humanism celebrates humanity for its own sake and its own perceived qualities resisting not only any supernatural or divine orientation but also scientific descriptions that position humans simply as part of (or at the top of) a 'natural order of things'. Humanism emerged from a reaction against religion or a God as the centre of all things (thus a humanist-agnostic/atheist tendency) toward a new centring around a reasoning humankind. In turn, humanism offered an ethics that was reason-based, that is, reason over emotions and prejudice rather than, say, a pure scientific rationalism (Lacey, 1995). As with any socially concerned group, positions amongst humanists vary according to values, philosophy or politics. Recently, UNESCO reports that: "Changes in the world call for the development of a new humanism that is not only theoretical but practical, that is not only focused 
on the search for values - which it must also be - but oriented towards the implementation of concrete programmes that have tangible results." (Bokova, 2010).

Emergent critiques show that the concept human, or its derivatives, cannot be taken as a 'given'. For a start, any centring of worldviews or actions based on the idea of human is itself inherently anthropocentric. Just as emergent humanism facilitated new ways of knowing and of conceptualising ourselves in a special 'human' way, so, as new understandings emerge, might the conceptualisation itself become redundant. "As the archaeology of our thought easily shows, man (sic) is an invention of recent date. And one perhaps nearing it's end." (Foucault, 1989/2000, p. 29). Here, post-humanism presents itself and we should briefly consider its two broad strands that speak to matters of ethics, education and democracy in relation to sustainability.

First, there is a humanities or social sciences postmodern sense of overcoming and reconceptualizing the human both inwardly and outwardly - looking inwardly to a reconceptualisation of the person and outwardly to all the relations (our coexistences) that we hold and which reciprocally shape us (Badmington, 2000; Fukuyama, 2003; Habermas, 2003; Bostrom, 2009; Wolfe, 2010). In this sense, Verbeek (2009, p. 251) discusses posthumanism as “...development beyond humanism as a predominant way of understanding what it means to be human." In this arena, we might say that constructs such as human and its relations are no longer sustainable.

Second, there is a more technological perspective of our human-technology coexistence which suggests, acknowledges or advances our transhumanism - as Verbeek (2009, p. 251) puts it: “...the 'transhumanist' development towards an enhanced version of Homo Sapiens..." Again, positions vary but one focal idea is that our merging technologies - across existences - are reaching a point described as Singularity (Vinge, 1993; Broderick, 2001; Kurzweil, 2005; Bostrom, 2009) and/or convergence (Schmidt, 2008) whereby we no longer talk of co-existence as existing 'with' or 'alongside' but, rather, as a fully integrated one. For Kurzweil (2005), posthumanism is the term for the period that will follow the Singularity in (views vary) three to five decades time. In this arena, we might say that constructs such as human and its relations are sustainable - at least through the Kurzweilian (1999, p. 14) take that technology is "evolution by other means".

Of course, there is the also the view of the future where human-caused planetary crises will lead to our own self-destruction - the doomsday scenario - pessimistic but plausible. In this post-extinction arena the question of human sustainability becomes null and Gaia (Lovelock, 1979) may be left to look after the planet. Bostrom (2009) offers four possible "families of scenarios for humanity's future" (Bostrom, 2009, p. 194) one of which is extinction. The others are recurrent collapse: "in which human civilization oscillates indefinitely within a range of technological development characteristic of a human condition" (Bostrom, 2009, p. 199) that is, peaking and troughing somewhere between our pre-human and the post-thuman states; plateau (of either technological increase reaching a plateau pre-posthumanism or of technological stasis close to the current level; and 
STEVE KEIRL

posthumanity (for which he offers several criteria and possible manifestations one of which is the "singularity hypothesis" (Bostrom, 2009, p. 204).

Whatever is happening in terms of humanity's evolution, we should note that: i) parallel discourses are developing which draw us into rethinking our understandings of being human; ii) those discourses should be taken into account in our thinking about sustainability - both as a concept and as action in, and on the world; iii) all the possible scenarios are fundamentally technological; iv) whatever the case, there are challenging ethical issues at play; and that, v) we need to rethink what an appropriate education might be for whichever circumstance we contemplate.

\section{Considering ethics...}

With any consideration of being human comes recognition that ethics is particularly and necessarily a human construct concerning our behaviour. "Moral value is something which springs into being only when there is an actual human agent deciding what to do, and doing it". (Warnock, 1970, p. 4). So long as people have interacted, ethics has been evidenced in mythology, in collaborative (rather than competitive) efforts towards coexistence, and in religion. All cultures and communities have developed moral codes and a rich interplay of emotion, spirituality, aesthetics, imagination, and more contribute to ethical coexistence. Sooner or later the classic ethical questions: How should I live? How should we live? What is right? What is good? and so on, are engaged by individuals and communities alike. Such questions beg discourses around values and the moderation of value differences is what can facilitate reasonable coexistence. That is, we act in ways that seek to understand, and to consider, values that we may not ourselves hold.

Midgley (1993, p. 3) reminds us that the origins of ethics can be considered in two particular ways: "... one about historical fact and the other about authority" and the distribution of both authority and agency are central to ethical values discourse and to the question of who gets to participate in ethical determinations. This is a highly significant issue when considering the extent, or otherwise, of participation in democratic decision-making around preferred and sustainable futures. The history of ethics also shows variations in its perceived practical value. Largely constrained to the Academy in the 1960s, "...(r)eal subjects..." subsequently became "...the proper concern of moral philosophers." says Warnock (1998, p. 1213). Fortunately, that trend has continued, greatly stimulated by the very real ethical issues presented by technologies.

Despite growth in the recognition of the need to see ethics-as-practice, whether for daily life or for technological assessment, pitfalls remain. There are challenges such as relativism ("It's all a matter of opinion") and those of religious and political dogma ("This is right/that is wrong"). As Blackburn has it: "There must be a course between the soggy sands of relativism and the cold rocks of dogmatism.” (Blackburn, 2001, p. 26). He also observes that “...one peculiarity of our present climate is that we care much more about our rights than about our 
'good"' (Blackburn, 2001, p. 4). Differently, we can have concerns about pervasive capitalism's capacity to colonise language to its own ends when it talks of 'ethical business' or 'ethical consumerism' as though such terms are 'innocent' (after Galbraith, 2004) when they might actually be greenwash, even oxymoronic. Solomon (1993) points to Aristotle's distinction between (acceptable) household trading "...essential to the working of any even modestly complex society..." and "...unsavoury and unproductive..." trade for profit. (Solomon, 1993, p. 355).

Today, most Western societies are being led and shaped by globalised capitalism that valorises egoistic or selfish self-interest over enlightened selfinterest. However, we have alternative ethical models to draw upon. To take just two: first, there are the deeply holistic perspectives and practices of Aboriginal peoples whose intimate relationship with land is generally beyond Western understanding but which is a paragon in the history of sustainability. Second, there is the principled assessment of technologies weighed against the communal good as practised by the Amish (Sclove, 1995; Kraybill, 1989/2001; Nye, 2007). Common criticisms applied by advocates of the dominant Western model to Aboriginal or Amish ways, are at worst a form of derision and at best a technical critique - one constrained to criteria of efficiency, profit, production and 'progress' (a now largely debunked bedfellow of capitalism). However, when an ethical perspective and analysis is applied to the varying models of ways-of-being-in-theworld, capitalist criteria alone are inadequate, impotent or, perhaps, are no longer sustainable.

Any pursuit of ethical criteria or for 'ways-to-be' ethically soon leads us to see why ethics (like Technology) is a contested field. Sometimes the breadth of contestation (as with Technology) leads people to indifference or apathy: "It's all too hard; what's the difference?; just get on with it". So it can help to know something of the options and issues at play. Somerville (2000) describes the 'schools of ethics' thus:

Among the diverse schools are principle-based or deontological ethics; situational ethics; utilitarian ethics; consequentialist ethics; casuist or casebased ethics (...similar to the legal doctrine of precedent); narrative ethics; feminist ethics; hermeneutical ethics (...based on interpretation of a context or text); and virtues or character ethics.... (Somerville, 2000, p. 289)

She points out that, if all of such 'schools' were to respond in unison to an ethical issue, there would be no ethical dilemma. However, it is more often the case that there is disagreement. Because ethics is about values and values difference, like design, it demands a weighing up of possibilities around matters that are controversial. Each of us has a value system or a set of values over which we have choices and it is for each of us not only to defend our values but also to modify them in the light of new experiences or better alternatives. Many associated concepts inform ethical or values discourse and help it have a presence in our daily thinking and behaviours. We debate terms such as good and right (and their counterparts); we discuss the respective merits of cooperation, collaboration and competition; we assess risk; we trust; we care; and, we develop empathy as 
STEVE KEIRL

both value and skill (Rogers, 2006). All such values have something about them which Warnock (1998) offers as 'timeless values': they turn up across the ages in all cultures and societies.

For each of us, tensions and contradictions arise when it comes to deciding how to act ethically, that is, to be a moral agent. Here, the question of the self returns. We might seek to educate to create the autonomous or self-determining individual but such an education would need to help the individual balance any claim to their 'rights' with an equal accommodation of their duties and responsibilities too. The concept of consciousness must also play a role. We can talk of levels of consciousness within the person (as with self-awareness) but there is also the degree of consciousness we hold towards the world beyond ourselves. In this realm it is possible to hold a false consciousness that masks one's awareness of the true state of the world at large. The term is drawn from Marxist theory to describe "...the masking effect of ideology, which cloaks the true conditions of things, thus inhibiting the mobilization of political activism." (Buchanan, 2010, p. 161). We have already witnessed Gadamer's (1975/2004) promotion of Bildung being grounded in understandings of working consciousness and cultivated consciousness while Keirl \& McLaren (2013) have written of altered consciousness with regard to choice and children's designing and technological thinking. All these configurations of consciousness must hold a place in shaping education for sustainability.

\section{Ethical being and the common good}

From a strongly argued a romanticist perspective, Beiser (2003) affirms Bildung as an on-going, holistic maximisation of self engaged in many fields of accomplishment whilst concurrently contributing to the maximised and holistic common good of multiple selves. To this we can add the Ancient Greek concept of eudaimonia, not readily translated but which can refer to happiness (though not in the purely subjective or selfish sense). This might be better expressed as welfare, human flourishing, or the pursuit of the highest human good. So, in considering ideas of what it means for people to be fulfilled, flourishing or achieving selfrealisation, we consider the good - not only for persons but for all people, that is, as a common good.

The idea of the common good is a worthy one but it has tended to be thought of as applying to and within particular communities or societies. As the witnesses attest, the common good must now be global and future-focussed. Are there particular ethical approaches that might contribute usefully to such an outlook? How might a practical ethics meet our aims? Certainly a deontological approach, (Greek deontos: duty) might inform our actions through prior-formulated rules or principles such as 'Do no harm'; a virtue ethics might inform our sense of how we should aspire to what is right and good; a narrative ethics might see ourselves in ethical stories; or a hermeneutic approach might invite ethical discourse as a matter of context-based interpretation. For the challenge of sustainability, all schools or 
dispositions of ethical thought have something to contribute but aspects of utilitarianism offer some particular possibilities.

Utilitarianism takes a consequentialist approach to ethics in that it is concerned with the weighing of the consequences of actions. In fact, Blackburn (2001) reminds us that utilitarian principles can be used to weigh other ethical approaches themselves. Often too simply described as 'the greatest happiness for the greatest number', our understanding can be deepened if we think instead of 'wellbeing' or 'interests' rather than the perhaps egoistic and subjective-sounding 'happiness'. As Griffin (1995) points out, we might think less in terms of 'number' (the quantitative) and more towards 'the optimum' (the qualitative). Thus, this is perhaps an ethics of optimising wellbeing or: "utility as welfare maximisation" (Goodin, 1993, p. 244). Utilitarianism is also an approach capable of considering multiple consequences and accommodating multiple agents including those beyond humans, on which, more below.

It is precisely because utilitarianism is forward-looking that it is of value to our concerns for all of: education, democracy and sustainability. While it may be informed by other ethical approaches or principles it is not bound by them. As Blackburn says:

It deals with value - with things being good or bad, or better or worse... Deontological notions of justice, rights, duties, fit into a moralistic climate, where things just are right or wrong, permissible or punishable. These are the words of law, as much as words of ethics. Utilitarianism by contrast gives us the language of social goods... (And, appropriately for this book's readership - SK) The cast of mind is that of the engineer, not the judge' (Blackburn, 2001, p. 75-76).

Also via utilitarianism, Midgley's (1993) 'authority' dimension of ethics can be a more distributed one. It is arguably better for more people to contribute to a forward-looking ethic than is possible when 'authority' lies in the hands of a few or is ascribed to a dogma. To paraphrase Goodin (1993, p. 248): 'What should we do, collectively?' is much more the utilitarian question than 'How should I live, personally?' This, of course, does not sit well with those few who would claim to hold moral authority and it is here that feminist ethical critiques have taken on matters of enculturation and gendered power distribution (see e.g. Tong \& Williams, 2011). Given some of the alternatives, there is a case to argue that utilitarianism offers a democratic means for ethical determination through debate and action pursued across time, place and cultures: that is, to effect a global ethical conversation. (Singer, 1993; Somerville, 2000; Blackburn, 2001; UNESCO, 2001, Berman, 2009).

\section{Ethics as practical action}

Ethics as it is embraced for this chapter is considered as practical philosophy for practical action for the sustainable good. Not only should the field be properly theorised but it should also be seen as a way forward, indeed, as a way of life or a 
STEVE KEIRL

way of being. To lay any claim as to how the future should be is surely to call forth an ethical position. Such is the case if we are to talk of sustainable futures.

While we might work from some prior established principles, shaping the future in an activist way brings some interesting considerations. In the literature it is not uncommon to come across Aldo Leopold's dictum: 'A thing is right when it tends to preserve the integrity, stability, and beauty of the biotic community. It is wrong when it tends otherwise' (see, e.g. Orr, 2005, p. 93, Haupt, 2011, p. 8). But is a 65 year-old rule sufficient to guide today's or future considerations? Perhaps. Its eloquence certainly exceeds the limiting and conditioning language of many current claims of what constitutes 'good' or 'right'. While the deontological approach has its merits it can be seen that Leopold's words beg much discussion if they are to inform 'right action' towards the future.

What emerges here are the different kinds of values under discussion. For example, Frankena (1973) distinguishes between moral and non-moral values, while we can also look to instrumental and intrinsic, or non-instrumental, values. One attempt at building on such distinctions sought to develop the idea of visioning values to serve future-focussed ethical-design curriculum (Keirl, 2006b). Being aware of these qualitative differences matters because the emergent debates become both personal and public in nature. For example, when it comes to the assessment of the designing and bringing into being of technologies, qualitative, moral and non-instrumental values must be engaged to appreciate the full picture. Many technologies (i.e. products) are produced simply for profit. Differently, for too long technological assessment has been little more than an increasingly subtle, coded language game around the lowest common denominator: "Does it work?" When Feenberg (2010) distinguishes between the cultural roles of technology and craft he notes the differentiation of technical activity and social activity: "Specifically, technical knowledge is separated out from the prevailing aesthetic and ethical values". Technical know-how is one thing but, in craft, the spectrum of values “...form a single complex" (Feenberg, 2010, p. 183).

\section{The temporal and ethics}

A few considerations should also be given to some temporal aspects of ethics in practice. For example, Somerville argues for 'ethics time' to conduct technological assessments - particularly with regard to major emergent technologies like xenotransplantation or nanotechnology. This resonates with 'slow' movement thinking configured as 'slow design activism' by Fuad-Luke (2010).

Design is a powerful vehicle by which to encourage people to aspire and achieve new ways of living, working and recreating. Design should spend less time on envisioning utopias and focus more on what American architect Bruce Goff called "the continuous present"....Design can reconnect us to a wider world where the ambition could be to encourage...eudaimonia, or human flourishing. Slow design offers that potent 'reconnection' to discover more eudaimonia. (Fuad-Luke, 2010, p. 150). 
Wood (2007) also looks to a future of eudaimonia that contributes to the good of others: 'Maintaining a quest for personal happiness is important, but it will also be vital to develop an active ethics of eudemonia (sic) that enshrines selfactualisation within situated altruism.' (Wood, 2007, p. 200).

While sustainability is forever concerned with the future, and design itself is about acting with intention on the future, history and hindsight both inform such perspectives. However a charge against some approaches to history is that of 'presentism': the judging or interpreting of past events using criteria of present-day moral views, that is: we ought not to judge the past by current ethical standards. Just as an extreme anthropocentrism can amount to speciesism ("...considered morally on par with sexism and racism" [Gruen, 1993, p. 350]) so we might think about our current moral perspectives and any risk of presentism. In anticipating 'preferred futures' we might acknowledge not only that we must hold our strongest and best-thought-through ethical case for acting towards the future, but also that we should be ready to adapt and reconsider that position as realities manifest themselves. Thus our ethically-grounded sustainability aspirations may simply need to be sustainably aspirational, that is, under continuous scrutiny for whatever would be (ethically) better.

The ethics literature (see eg Singer, 1993) highlights the problematics around intention and foresight and technology researchers have begun to signal caution towards any claim to certainty of outcome regarding designed futures. Tenner (1997) reported on the unintended consequences and 'revenge effects' of designed technologies and, building on earlier work around the intentional fallacy (from literary criticism), Ihde (2006) has offered the designer fallacy as a caution against congruence between any designer intention and a technology's use.

With foresight in mind there has been much expression over the last three decades of the precautionary principle which suggests that unless there is consensus or evidence that harm will not occur, or that consequences are fully understood, then a new technology should not be developed. As Sunstein's (2005) critique of the principle shows, there is a plethora of issues at play in the assessment of risk, for example: fear; precaution versus paralysis; compromise of civil liberties; expertise vs ignorance; short-termism of people and governments alike; people being "unrealistically optimistic"; or their tending "...to reduce cognitive dissonance, sometimes by treating risks as though they are tiny, even worth ignoring" (Sunstein, 2005, pp. 52-53). Sunstein's work cautions us ethically, socially and politically about the limits and potential of the precautionary principle. Once more, for all a seemingly valid and well-intentioned ethical 'principle' can inform considerations about sustainability, it must be maintained under critique for its limitations. Whether looking to the future; trying to act ethically towards the future; trying to design, or to 'engineer' the future; it would seem appropriate to move with a nuanced blend of ethics of intention and an ethics of caution. 
STEVE KEIRL

Moral considerability and those others with whom (and with which) we coexist

Moral philosophy also debates an important concept regarding our several coexistences. Moral considerability emerges from the question of how we treat others. Writing on world poverty, Dower (1993) argues that people, as moral agents with choices, should consider the effects of their choices on the wellbeing of others. It doesn't matter whether the 'others' are part of the same moral community as those with choices. What is significant is that moral consideration is extended to others. In turn, under a life-centred ethics, anything living is eligible for moral consideration: "...even the whole biosphere itself...A life-centred ethic counts all living things as morally considerable although not necessarily of moral significance" (Elliot, 1993, p. 287).

But should matters rest there? With the Singularity comes the blurring of the natural and the artificial, and the interface of the bitsphere and the biosphere (Franklin, 1990/2004). As Bennett (2010) speculates: "Perhaps the ethical responsibility of an individual human now resides in one's response to the assemblages in which one finds oneself participating..." (Bennett, 2010, p. 37). Verbeek (2006) has argued for moral considerability towards 'things' - all those technologies that mediate our lives, with which we also coexist.

...(T)he argument that things do not possess intentionality and cannot be held responsible for their "actions" does not justify the conclusion that things cannot be part of the moral community...

When the actions of human beings are not only determined by their own intentions but also by the material environment in which they live, the central place of the autonomous subject in ethical theory needs to be put in perspective. Once we do that, it becomes clear that it might indeed be necessary to move the source of ethics, which had already been moved from God to humans, one place further. (Verbeek, 2006, p. 121).

Verbeek doesn't declare the concept of human to be obsolete but, rather, he advocates a posthumanist ethics that need not abandon humanist values, giving "...a central place to the idea that the human can only exist in its relations to the non-human...(and)...In order to cultivate humanity, we need to take seriously how technologies also help to cultivate us." (Verbeek, 2009, p. 261).

\section{Established and emergent technologies}

Apart from all that we are gradually learning to critique about existing technologies, we have a spectrum of emergent technologies that are both accelerating the re-shaping of our (co)existences and formimg the foundations for the Singularity and Bostrom's (2009) scenarios. Major candidates include: nanotechnologies; xenotransplantation; artificial intelligence; and, genetic engineering (of any species). Most recent is 'big data' which brings its own capacities for reshaping existences in ethically problematic ways. The well- 
established issue of data quality (garbage in/garbage out) becomes hugely magnified: "We are more susceptible than we many think to the "dictatorship of data' - that is, to letting the data govern us in ways that may do as much harm as good." (Mayer-Schönberger \& Cukier, 2013, p. 166). Issues of privacy, still not fully understood, are now compounded by issues of probability: “...the risk that we may judge people not just for their actual behaviour but for propensities the data suggests they have." (Mayer-Schönberger \& Cukier, 2013, p. 192, my italics). When policymakers or businesses have access to, and control over, mass data, all of democracy, education and sustainability become ethically challenged. The fact remains that, established or emergent, every technology is an ethically complicated navigation of values.

This very fact is a pointer to the challenge of trying to 'see' technologies for what they are. Whether a canal, a washing-up brush or a form of government, the mistake is in trying to understand any technology as an 'it' rather than the holism it represents. Technologies can be critiqued holistically, democratically, ethically and sustainably by interrogating their circumstances across five interdependent phases: intention; design; realisation; use; and, consequences (Keirl, 2009). Conducting such interrogations opens up the ethics of coexistences, futures and our very sense of being human. Further, issues of our democratic engagement in, or marginalisation from, technological enactments also raise questions around choice as moral agency or choice as illusion. If choices are only presented to us at the realisation stage (once a technology has come into being) then our capacity for effective, democratic choice-making is greatly reduced. In such a situation, it is already too late to discuss sustainability concerns which begged critique at the very intention stage - even before any designing is undertaken.

It has been the absence of democratic participation at these early phases of a technology's development that has disempowered citizens and publics from helping shape sustainable futures. For too long our ethical perspectives have been reactive rather than proactive: witnessed by the cycle of technological creation negative consequence - remedial legislation. Street talk still echoes Enlightenment/capitalist faith in 'progress' and simplistic technological determinism (see e.g. Smith \& Marx, 1994) both of which position citizens as mute and powerless in technological decision-making.

\section{Developing the necessary conversations}

It can be argued that we are somewhat 'caught' at present in that, not being used to collective determination of possible and preferred futures, we are conditioned to accept that "that's the way things are going" as our (determined) lot in life. There are two ways we might think about the future. First, there is the Future (big 'F') a whole, not just something ahead of now but a way of being, living, relating, feeling and knowing. The Future in this holistic, amorphous sense is not only unknown but is imagined by each of us in differing ways. Nonetheless, the Future is something towards which we can offer moral considerability and we can do this through multiple conversations. Thus, while we can talk reflectively and 
STEVE KEIRL

imaginatively about the Future, we can also talk pragmatically about, and act on, a range of futures (small ' $\mathrm{f}$ ') - multiple and coincident because of our coexistences. Our personal futures are considered not only alongside those of other people but also alongside those of other species, technologies, and the planet.

While education is key to developing citizen engagements in ethically defensible global futures, any such education needs to work across communities, societies, cultures and boundaries (whether physical, political or otherwise). It needs to be multi-located: in homes; through responsible media; in the street; through policy; and, in formal educational settings. In turn, multiple conversations are needed, both deliberative and activist, around a range of futures-orientated concepts that can inform an ethics of sustainability. From what has been said, these could include:

- The problematics of self, of human, of other;

- The interests of whoever and whatever constitutes the moral community including both knowledge interests (Habermas, 1971) and 'self' interests;

- Bostrom's (2009) scenarios for humanity's future;

- Maintaining ideal visions as practical, futures-focussing devices (candidates include: democracy, Bildung, eudaimonia, the common good);

- Moral imagination and creativity (Warnock, 1998; Mackay, 2004; Somerville, 2006);

- Empathy and multiple forms of consciousness;

- Choice and all its manifestations from Singer's (1995) ultimate choices to our daily choices and the moral context of choice-making;

- Rights and responsibilities as ethics of democracy and ethics of duty;

- Moral considerability across all four realms of co-existence;

- Design, utilitarianism and consequentialism as futures-orientated;

- Ethics time and timeless values;

- Care: "Caring is primarily forward-looking in orientation." (Dower, 1993, p. 275); and,

- Ethics as engineering (or design) rather than judgement.

This is not an ethical checklist and the concepts exemplify how ethics (as with sustainability itself) is a process rather than a destination. To build and to maintain conversations around these concepts is to build a discourse of, and for, sustainability. Both Warren (1995) and Blackburn (2001) report Habermas's case for a discourse ethics that is dialogical in nature and seeks to facilitate conversations between concerned parties. Fuad-Luke's design activism advances “...participatory democratic spaces for co-design decision-making in the form of a MootSpace, building on historic examples (the Anglo-Saxon moot) and contemporary practices (the Maori marae)" (Fuad-Luke, 2010, p. 151). Meanwhile, to return to the fifth witness, UNESCO cautions that:

All of us involved in the dialogue on ethics must be aware of our own cultural references and roots, and must not claim universality, nor blindly pretend to cultural 'neutrality'. Our hope is to raise awareness of the deep world heritage of ethical wisdom, and to promote mutual learning and 
understanding for an 'authentic' dialogue on the values that are to guide the evolution of the 21" Century. (UNESCO, 2001, Annex II, p. 5)

In the Western world, we have been conditioned to measure life instrumentally and competitively within and across national borders. But there is significant difference between 'standard of living' and 'quality of life' and it is the latter which is the concern of the witnesses. To advance sustainability in ways that qualitatively enhance the wellbeing of all that exists on the planet can only be done by a comprehensive and ongoing engagement with a global ethics. In advancing a case for the consideration of ethics for sustainability I have also argued the ethical interdependence of sustainability, democracy and education (and, thus, Design and Technology education) - that they speak to, for, and of, each other ethically. To advance the quality of one is to advance the quality of them all.

As Blackburn says: "Ethics is disturbing" (Blackburn, 2001, p. 7) but then so is the enormity of our global concerns. Ethics today is developing as a versatile, practical, philosophical tool but skills in using and maintaining the tool are needed by everyone. Hence the role of education and the global village in helping students become skilful ethical practitioners and activists. Education and, thus, Design and Technology education, now faces a major set of choices around whether it will be maintainer of the status quo or agency of change for heightened global ethical consciousness and practice.

\section{Coda}

This chapter has offered only a selective overview of some key fields of enquiry not least, ethics itself. Several 'isms' warrant expansion, notably: determinism, humanism, existentialism, idealism, and anthropocentrism. A similar case stands for a range of 'posts-', notably: posthumanism (Wolfe, 2010); postmaterialism (Bennett, 2010); and, regarding technologies, postphenomenology (Ihde, 1993; Selinger, 2006). Any use of the term 'nature' must be carefully critiqued (Singer, 1993; Habermas, 2003). As already noted, a major limitation is the Western orientation of the chapter. An obvious candidate for expanded discussion would be the ethics of craft practices (see e.g. Fry, 1992; Berger, 2003; Sennett, 2008; Gauntlett, 2011). Finally, and perhaps most telling, has been the avoidance of any settlement on a particular 'working definition' of sustainability itself. The conversations continue...

\section{REFERENCES}

Apple, M.W., (2001), Educating the "Right" Way: markets, standards, God and inequality, Routledge Falmer, New York.

Badmington, N., (Ed.), (2000), Posthumanism, Palgrave, Basingstoke.

Beiser, F.C., (2003), 'Romanticism', in Curren, R., (Ed.), (2003), A Companion to the Philosophy of Education, pp.130-142, Blackwell, Oxford.

Bennett, J., (2010), Vibrant Matter: A Political Ecology of Things, Duke University Press, London. 


\section{STEVE KEIRL}

Berger, R., (2003), An Ethic of Excellence: Building a Culture of Craftsmanship with Students, Heinemann, Portsmouth, NH.

Berman, D.B., (2009), do good How designers can change the world, New Riders-AIGA, Berkeley, CA.

Blackburn, S., (2001), Ethics: A very short introduction, Oxford University Press, Oxford.

Bokova, I., (2010), A New Humanism for the $21^{\text {st }}$ Century, UNESCO, Paris. URL:

http://www.unesco.org/new/en/media-services/single-

view/news/a new humanism for the 21st century-1/A.VEvYK0bLRdo

Bostrom, N., (2009), 'The Future of Humanity', in Olsen, J.K.B., Selinger, E. \& Riis, S., (Eds.), (2009), New Waves in Philosophy of Technology, pp.186-215, Palgrave Macmillan, Basingstoke, UK.

Broderick, D., (2001), The Spike: How our lives are being transformed by rapidly advancing technologies, Forge, New York.

Buchanan, I., (2010), A Dictionary of Critical Theory, Oxford University Press, Oxford.

Chomsky, N., (1989/2003), Necessary Illusion: Thought control in democratic societies, Anansi, (2003), Toronto.

Dower, N., (1993), 'World Poverty' in Singer, P., (1993), (Ed.), A Companion to Ethics, pp.273-283, Blackwell Publishing, Oxford.

Elliot, R, (1993), 'Environmental Ethics' in Singer, P., (1993), (Ed.), A Companion to Ethics, pp.284293, Blackwell Publishing, Oxford

Feenberg, A., (2010), Between Reason and Experience and Experience: Essays in Modernity and Technology, MIT Press, Cambridge, MA.

Foucault, M., (1989/2000), 'The Order of Things: An Archaeology of the Human Sciences' in Badmington, N., (Ed.), (2000), Posthumanism, pp.27-29, Palgrave, Basingstoke.

Frankena, W., (1973), Ethics, Prentice-Hall, Englewood Cliffs, N.J.

Franklin, U.M., (1990/2004), The Real World of Technology, Anansi, Toronto.

Fry, T., (1992), 'Green Hands Against Dead Knowledge' in Ioannou, N., (1992), Craft in Society, An Anthology of Perspectives, Fremantle Arts Centre Press, South Fremantle, WA.

Fry, T., (2009), Design Futuring: Sustainability, Ethics and New Practice, Berg, Oxford.

Fuad-Luke, A., (2010), 'Adjusting our Metabolism: Slowness and Nourishing Rituals of Delay in Anticipation of a Post-Consumer Age', in Cooper, T., (Ed.), (2010), Longer Lasting Products: Alternatves to the Throwaway Society, pp.133-155, Gower, Farnham, UK

Fukuyama, F, (2003), Our Posthuman Future: Consequences of the biotechnology revolution, Picador, New York.

Gadamer, H-G., (1975/2004, $2^{\text {nd }}$ Edn.), Truth and Method, (Trans. Weinsheimer, J. \& Marshall, D.G.), Continuum, London

Galbraith, J K., (2004), The Economics of Innocent Fraud, Penguin, London

Gauntlett, D., (2011), Making is Connecting: The social meaning of creativity, from DIY and knitting to YouTube and Web 2.0, Polity Press, Cambridge UK.

Goodin, R.E., (1993), 'Utility and the good', in Singer, P., (1993), (Ed.), A Companion to Ethics, pp. 241-248, Blackwell Publishing, Oxford

Griffin, J.P., (1995) 'Consequentialism' in Honderich, T., (1995), The Oxford Companion to Philosophy, Oxford University Press, Oxford.

Habermas, J., (1971), Knowledge and Human Interests, Beacon, Boston.

Habermas, J., (2003), The Future of Human Nature, Polity Press, Cambridge.

Haupt, L.L., (2011), Crow Planet: Essential Wisdom from the Urban Wilderness, Back Bay Books/Little, Brown and Company, New York.

Ihde, D., (1993), Postphenomenology: Essays in the postmodern context, Northwestern University Press, Evanston, Illinois.

Ihde, D., (2006), 'The Designer Fallacy and Technological Imagination' in (Ed.) Dakers, J.R., (2006), Defining Technological Literacy: Towards an epistemological framework, pp 121-131, Palgrave Macmillan, Basingstoke. 


\section{GLOBAL ETHICS, SUSTAINABILITY, AND D\&T EDUCATION}

Keirl, S., (2006a), 'Ethical technological literacy as democratic curriculum keystone' in (Ed.) Dakers, J.R., (2006), Defining Technological Literacy: Towards an epistemological framework, pp 81-102, Palgrave Macmillan, Basingstoke.

Keirl, S., (2006b), 'The Ultimate Design Question: "How should we live?" as catalyst for 'Visioning values' in Design and Technology Education.' in (Ed) Middleton, H., (2006) Values in Technology Education: Proceedings of the 4th Biennial International Conference on Technology Education Research, (pp 201 -210), Surfers Paradise, Australia, 7-9, Dec. 2006.

Keirl, S., (2009), 'Seeing Technology Through Five Phases: a theoretical framing to articulate holism, ethics and critique in, and for, technological literacy' in Design and Technology Education: An International Journal, (2009), Vol 14, No. 3, pp 37-46. URL: http://jil.lboro.ac.uk/ojs/index.php/DATE/article/view/1274/1239

Keirl, S., (2010), 'Critiquing and Designing as Thinking Tools for Technology Education for Sustainable Co-existence' in Hansen, R. \& Petrina, S. (Eds.), Proceedings of the Technological Learning and Thinking: Culture, Design, Sustainability, Human Ingenuity Conference, pp 531-540, $\begin{array}{lllll}\text { Vancouver, } & \text { BC, } & \text { 17-19 June, } & \end{array}$ http://m1.cust.educ.ubc.ca/conference/index.php/TLT/2010/paper/view/57/5

Keirl, S. \& McLaren, S,V., (2013), 'Students as choice-makers: developing altered consciousness as an aspect of design and global citizenship literacy', in (Eds.), Reitan, J.B., Lloyd, P., Bohemia, E., Nielsen, L.M., Digranes, I. \& Lutnæs, I., Design Learning for Tomorrow: Design Education from Kindergarten to PhD: Proceedings from the 2nd International Conference for Design Education Researchers: (Vols 1-4), (Design Research Society/CUMULUS the International Association of Universities and Colleges of Art, Design and Media, 14-17 May 2013, Oslo, Norway), Vol. 3, pp1611-1625, ABM-media/Oslo and Akershus University College of Applied Sciences, Oslo.

Kraybill, D.B., (1989/2001), The Riddle of Amish Culture, The John Hopkins University Press, Baltimore.

Kurzweil, R., (1999), The Age of Spiritual Machines: When computers exceed human intelligence, Allen \& Unwin, St Leonards, N.S.W.

Kurzweil, R., (2005), The Singularity is Near: When humans transcend biology, Penguin, London

Lacey, A.R., (1995), 'Humanism' in Honderich, T., (Ed.), (1995), The Oxford Companion to Philosophy, pp.375-376, Oxford University Press, Oxford.

Latour, B., (2007), Reassembling the Social: An Introduction to Actor-Network-Theory, Oxford University Press, Oxford.

Lovelock, J.E., (1979) Gaia, a New Look at Life on earth, Oxford University Press, Oxford.

Mackay, H., (2004), Right and Wrong: how to decide for yourself, Hodder, Sydney.

Mayer-Schönberger, V. \& Cukier, K., (2013). Big Data: A Revolution that will Transform how we Live, Work and Think, John Murray, London.

Midgley, M., (2001), 'The Origin of Ethics', in Singer, P., (1993), (Ed.), A Companion to Ethics, pp.313, Blackwell Publishing, Oxford

Nye, D.E., (2007), Technology Matters: Questions to live with, The MIT Press, Cambridge, Massachusetts.

Orr, D.W., (2005), 'Place and Pedagogy' in Stone, M.K. \& Barlow, Z., (Eds.), (2005), Ecological Literacy: Educating our children for a sustainable world, pp.85-95, Sierra Club Books, San Francisco.

Packard, V., (1957/1962), The Hidden Persuaders, Pelican, Harmondsworth.

Packard, V., (1960/1963), The Waste Makers, Pelican, Harmondsworth.

Rogers, M., (2006), 'Design and Technology Education in a Social Context' in (Eds.) Inman, S. \& Rogers, M., (2006), Building a Sustainable Future: Challenges for Initial Teacher Training, pp.101110, World Wildlife Fund (WWF-UK), Godalming, UK.

Schmidt, S., (2008), The Coming Convergence: Surprising ways our diverse technologies interact to shape our world and change the future, Prometheus Books, New York.

Schumacher, E.F., (1973/1974), Small is Beautiful, Abacus, London.

Sclove, R.E., (1995), Democracy and Technology, The Guilford Press, N.Y. 


\section{STEVE KEIRL}

Selinger, E., (Ed.), (2006), Postphenomenology: A Critical Companion to Ihde, State University of New York Press, Albany.

Sennett, R., (2008), The Craftsman, Yale University Press, New Haven.

Singer, P., (1993), (Ed.), A Companion to Ethics, Blackwell Publishing, Oxford.

Singer, P., (1995), How are we to live? Ethics in an age of self-interest, Mandarin, Port Melbourne.

Singer, P., (2004), One World: the ethics of globalisation, Yale University Press, New Haven.

Smith, M.R. \& Marx, L., (1994), Does Technology Drive History? The Dilemma of Technological Determinism, The MIT Press, Cambridge, Massachusetts.

Solomon, R.C., (1993), 'Business Ethics' in Singer, P., (1993), (Ed.), A Companion to Ethics, pp.354365, Blackwell Publishing, Oxford

Somerville, M.A., (2000), The Ethical Canary: Science, society and the human spirit, Viking/Penguin, Harmondsworth.

Somerville, M.A., (2006), The Ethical Imagination: Journeys of the Human Spirit, Melbourne

University Press, Carlton, Vic.

Sunstein, C.S., (2005), Laws of Fear: Beyond the Precautionary Principle, Cambridge University Press, Cambridge.

Tenner, E., (1997), Why Things Bite Back: Technology and the revenge of unintended consequences, Vintage, New York.

Tong, R. \& Williams, N., (2011), 'Feminist Ethics', in Zalta, E.N., (Ed.), (2011), The Stanford Encyclopedia of Philosophy (Summer 2011 Edition), URL http://plato.stanford.edu/archives/sum2011/entries/feminism-ethics/

United Nations Educational, Scientific and Cultural Organisation (UNESCO), (2001), Ethics for the $21^{s t}$ Century, UNESCO, Paris. URL: http://unesdoc.unesco.org/images/0012/001246/124626Eo.pdf

Verbeek, P-P., (2006), 'The Morality of Things: A Postphenomenological Inquiry' in Selinger, E., (Ed.), (2006), Postphenomenology: A Critical Companion to Ihde, pp.117-128, State University of New York Press, Albany.

Verbeek, P-P., (2009), 'Cultivating Humanity: Towards a Non-Humanist Ethics of technology' in Olsen, J.K.B., Selinger, E. \& Riis, S., (Eds.), (2009), New Waves in Philosophy of Technology, pp.241-263, Palgrave Macmillan, Basingstoke, UK.

Vinge, V., (1993), What is The Singularity? URL: http://mindstalk.net/vinge/vinge-sing.html

Warnock, M., (1970), Existentialism, Oxford University Press, Oxford.

Warnock, M., (1998), An Intelligent Person's Guide to Ethics, Duckworth, London.

Warren, M.E., (1995), 'The Self in Discursive Democracy' in White, S.K., (Ed.), (1995) The Cambridge Companion to Habermas, pp.167-200, Cambridge University Press, Cambridge.

White, P.A., (1973), 'Education, Democracy, and the Public Interest', in Peters, R.S. (ed.), (1973), The Philosophy of Education, Oxford University Press, London.

Wolfe, C, (2010), What is Posthumanism? University of Minnesota Press, Minneapolis.

Wood, J., (2007), Design for Micro-Utopias: Making the Unthinkable Possible, Gower. Aldershot, UK.

\section{Steve Keirl}

Technology Education Research Unit, Department of Design

Goldsmiths, University of London 